\title{
To be or not to be; the EU cross-border mergers framework and harmonization of dissenting shareholder's rights
}

\author{
Hamed Alavi* \\ TATSIANA KHAMICHONAK**
}

\begin{abstract}
To date, the Cross-border Merger Directive is known as a successful attempt in harmonizing crossborder merger rules within the overall under-harmonisation of EU company law. Transnational companies merge across the Union in accordance with the European cross-border mergers framework. However, concerns in many respects are not met. Issues like descending shareholder protection and creditors' rights still raise valid questions. The legal aspects of dissenting shareholders' rights and their protection against the majority decision are notharmonized at the Union level and leave the issue under the control of the national law of the Member States. Therefore, the Member States provide divergent levels of protection for dissenting shareholders of a cross-border merger transaction within their national framework. Such divergence extends from providing no special rights for minority shareholders in cross-border mergers to transposing the respective provision in the Cross-Border Mergers Directive in national laws and provide particular remedies for such group of shareholders in cross-border mergers taking place subjected to their national law. This paper endeavors to answer the question of 'Whether or not further harmonization of protection mechanisms for dissenting shareholders within cross-border merger transactions in the EU necessary?'.
\end{abstract}

Keywords: minority shareholders, dissenting shareholders, shareholder voting, cross-border merger, Cross-Border Merger Directive, protection of dissenting minority shareholders.

\section{INTRODUCTION}

The European legislation has developed the framework approach to overcome the issue of dissenting shareholders while giving a high level of discretion to the Member States. According to consultations done by the commission, stakeholders expressed diverse advises, where high percentage of them commented against the further harmonization of harmonization of dissenting shareholder's rights, the majority voted for in favour of it. ${ }^{1}$ The absence of consensus regarding the necessity for further harmonization is also confirmed by academicians. This paper is evaluating the question whether lack of harmonization in regulating minority shareholder rights will affect efficiency of crossborder mergers at the EU level? To answer the main research question, this paper has the following structure: The introduction is followed by part II which differentiates dissenting and minority shareholders while explaining general role of shareholders in decision-making process of a given company. Part III articulates the shareholder's role during the merger transaction in accordance with Cross-Border Merger Directive and need for protecting dissenting shareholders based on cross-border nature of transaction. Part IV will

* Lecturer, Tallinn Law School Tallinn University of Technology Ehitajate Tee 5, 19086 Tallinn Estonia hamedalavi2000@gmail.com

** Tatsiana Khamichonak, LLM Vrije Universiteit Amsterdam, tatsiana.khamichonak@hotmail. com

${ }^{1}$ European Commission <http://ec.europa.eu/internal_market/consultations/2014/cross-bordermergers-divisions/docs/summary-of-responses_en.pdf $>$ accessed 20 December 2016 
describe status quo in protection of desisting shareholder rights in the Member States as well as in the Union besides answering the question whether further harmonization in the area is required.

\section{SHAREHOLDERS: THEIR ROLE IN A COMPANY'S DECISION MAKING PROCESS}

Shareholders are generally known as company owners, but scholars have questioned such belief, as it does not represent the true position of shareholders with in the company. ${ }^{2}$ It might be better to define shareholders as owners of the company's shares with collective power to exercise control over it, while experts are hired to manage it. ${ }^{3}$ Both definitions might seem quite similar, but their difference will become evident when considering small shareholders. Different legal and natural entities may be shared disproportionately in a company whose shares do not fully belong to one shareholder. For example, in firms like Apple Inc., Microsoft and Facebook, a huge crowd of shareholders own small numbers of shares. Ownership of company shares for small shareholders only results them in them earning dividends and disposable share rather than providing them with control of the company. ${ }^{4}$

Managers and directors run the firms. They are hired to execute the business independently from the shareholders. However, investment in a company creates interest in success of its business for all shareholders regardless of their number of shares. Such success will be created only by business expansion via making wise and timely decisions and maximization of profit. Therefore, shareholders are entitled to take part in a company's decision-making process. The main methods of reacting to management and expressing their opinion are either by voice or exit, ${ }^{5}$ the selling of shares by shareholder and leaving the firm. This provides the shareholder with an escapeway from a company trapped in troubles. However, exit does not offer any solution for exiting technical or managerial problems in the business and may even negatively affect the market in which the firm operates. 'It reduces the market efficiency and increases the potential number of corporate failures, which could be avoided by the exercise of a shareholder's voting rights' ${ }^{6}$ As a result, voting is the preferable way for expressing the opinion and affecting the course of the company's management. ${ }^{7}$

According to main economic theory of the voting rights, an outstanding reason for shareholders to cast a vote is expression of opinion about the business of the company. The reasons behind disparity between interests of the company expressed in shareholders voice and its directors were, as explained by Adam Smith: 'The directors of such companies [joint-stock], being the managers rather of other people's money than of their own, it cannot as well be expected that they should watch over it with the same anxious vigilance with which the partners in a private co-partnery frequently watch over their own'. ${ }^{8}$ Further, intrinsic right in nature of membership based on the rights-based theory gives an explanation

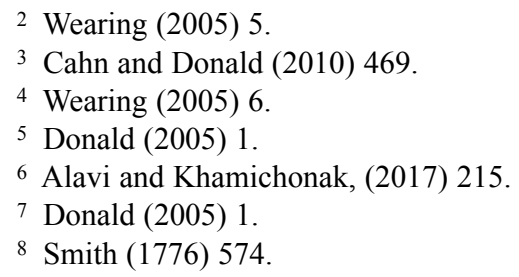


for getting to vote by shareholders. Also, the shareholder democracy theory, by comparing rights of citizens in a democratic state with those of shareholders', considers such individual rights as a reliable tool to keep the management accountable. ${ }^{9}$ The common area in all above-mentioned theories is considering the entitlement of shareholders to express their voice to management regardless of their majority or minority position.

The voting mechanism is designed in a way that it increases the influence of a shareholder according to shares held by them. ${ }^{10}$ Therefore, in accordance with the principle of one share one vote, holding less shares will bring less influence in general meeting of shareholders. Voting process will take place on different occasions relevant to the business conduct by the firm. However, the main cases are those relevant to constitutional documents, assets and structural integrity of the company. ${ }^{11}$ In the case of a cross-border merger such issues are highly relevant, and opinions of all shareholders are counted. However, as mentioned earlier, company law matters are largely left to the discretion of the Member States and; therefore, the matters on which shareholders vote differ across The EU. Information and other rights of shareholders, voting rights, and the protection afforded to them are also regulated on the national level. Besides the framework provisions of the SE and Cross-Border Mergers Directive, there is no European instrument harmonizing shareholders' rights and responsibilities in private limited companies, let alone protection of the minority in cross-border mergers.

\subsection{Dissenting and minority shareholders - synonymous or not?}

Naturally, it is in the course of business that majority and minority shareholders' views can clash. ${ }^{12}$ For the sake of securing the effectiveness of the company's functions, decisions within a company are taken by majority. ${ }^{13}$ However, it is submitted that small shareholders need additional protection, as their lesser bargaining power may subject them to abuse by the majority. As a result, it is necessary to look for a solution to safeguard legitimate interest of minority shareholders within a decision making process based on majority. ${ }^{14}$

Within the EU law, neither minority shareholders are defined, nor there is a comprehensive framework to protect their rights. This could be due to the notion of 'minority' as a relative concept that is conditional on the presence of a 'majority'. ${ }^{15}$ A 'minority' can be thought of in connection to voting rights or capital prevalence, which are not necessarily the same thing. ${ }^{16}$ By voting at a general meeting, decisions are usually taken by the majority because of imposing a higher quorum requirement can jeopardize the efficient functioning of a company. Majority is any percentage of votes in favor of a decision that is higher than $50 \%$. Accordingly, $51 \%$ is considered a simple majority. Such figures are fully dependent on a company's articles of association regulated by national laws of Member states. Usually, higher quorum is suggested by statute for perceivably more important decisions that alter the business and structure of a company including: the

9 Cahn and Donald (2010) 473.

10 Cahn and Donald (2010) 470.

11 Cahn and Donald (2010) 478.

12 Alavi and Khamichonak (2016) 72.

13 Wyckaert and Geens (2008) 40.

14 Wyckaert and Geens (2008) 40.

15 Perakis (2004) 17.

16 Perakis (2004) 17. 
amendment of constitutional documents of a company and company restructuring, among others, including a merger. These decisions at a general meeting should be taken by higher majority rates of $2 / 3$ or $3 / 4$ of votes. ${ }^{17}$ In case of a merger the Third Directive prescribes that approval of the general meeting 'shall require a majority of not less than $2 / 3$ of the votes attached either to the shares or to the subscribed capital represented' ${ }^{18}$ However, if at least half of the subscribed capital is represented at a general meeting, then a simple majority will suffice to adopt the decision. ${ }^{19}$

It is important in the context of voting at a general meeting. The concept of 'minority' is loosely defined in national law by reference to the amount of shares that a shareholder holds. That is e.g. anything lower that $10 \%$ of the share capital puts the shareholder in a minority. The amount of shares, however, does not necessarily put a shareholder in a position that warrants protection at a general meeting that approves a cross-border merger. Deciding collectively and deciding in favor of merger leaves the majority shareholder satisfied with the course of action and does not demand special treatment. Indeed, it is the minority shareholders that vote against a merger the dissenting shareholders that need the safeguards in a cross-border merger transaction. Ideally, any percentage lower than $51 \%$ (majority) should be covered by minority protection rules because once the majority have decided in favor of a merger, the transaction goes through regardless of the dissenting votes.

\section{SHAREHOLDERS AND THEIR INVOLVEMENT IN THE CROSS-BORDER MERGER TRANSACTION}

Compliance of the merging company with national laws of the Member State which it is subject to are stipulated in Article 4(1) (b) of the Cross-Border Mergers Directive. The implementation of the Third Company Directive resulted in achieving some level of harmonization in case of public limited companies. However, private limited companies are regulated by the Tenth Directive. The unregulated issues not touched upon by that directive are subject to measures provided in domestic laws, e.g. mechanisms to protect dissenting minority shareholders. Harmonization of the procedural steps in the context of cross-border mergers is a major achievement of the Tenth Directive. Authors believe it is instrumental to analyze preparatory steps leading up to a merger in order to estimate the degree of shareholders' involvement and protection.

Preparation of the common draft of a merger's terms by each participating company is the first step in starting the process. The draft includes the name, form and registered addresses of both merging and resulting companies, kinds of adverse effects which the merger can impose on employees, share exchange ratio, and statutes for the resulting company from the moment it starts the accounting procedure. ${ }^{20}$ Unless the draft terms are constantly available on the website of all participating companies, they need to publish it according to their national laws by a month before the general meeting. ${ }^{21}$ The address in which complete information about arrangements is available to shareholders of each company should be published in the national gazette. ${ }^{22}$

17 Perakis (2004) 17.

18 Mergers Directive Article 7(1).

19 Mergers Directive Article 7(2).

20 Article 5.

${ }^{21}$ Article 6(1).

22 Article 6(2). 
All legal and economic effects of the merger should be explained in a management report for shareholders, creditors and employees before starting the process. The report must be accessible one month before the general meeting of each merging company. ${ }^{23}$ Additionally, draft terms of the merger should be examined in an independent expert report available to all shareholders by one month before the general meeting. ${ }^{24}$ The share exchange ratio and its method of calculation should be explained in the report plus fairness of calculations in accordance with the market price. ${ }^{25}$ The agreement of all shareholders to vote in favor of the merger can override requirement of presenting examination and expert report. $^{26}$

All above mentioned documents including draft terms of the merger, management report and expert survey form a bundle which acts towards meeting the right of shareholders for access to sufficient information about the merger process. In addition, shareholders enjoy economic and governance rights. ${ }^{27}$ The rationale behind access to information right is ensuring shareholders to make informed decisions about business of the company, monitor the performance of their investment and observe management decisions in the company. ${ }^{28}$ The governance and Information rights are closely linked to each other. Access to precise and correct information will enable shareholders to make insightful decisions about fundamental company matters, e.g. capital and ownership structure, management problems, entering into a cross-border merger process and seeking for available remedies. ${ }^{29}$ The information rights of shareholders are embodied in the Tenth Directive without reference to minority shareholders. The only specifically designed provision is contained in the Article 6(2), discussed earlier.

The general meeting of each merging company should approve the draft of common terms of the merger. ${ }^{30}$ The general meeting is a manner for making decision on corporate matters not in the scope of management authority. It functions based on collective shareholders' votes. ${ }^{31}$ The EU law provides a limited insight into issues subjected to shareholder votes, e.g. approval of the merger in cross-border mergers. (Article 9). Issues to be decided in general meeting are regulated in national law of the Member States. For example, election of the board members is regulated differently across the EU. ${ }^{32}$

The importance of a decision in the agenda of a general meeting is the factor for defining the number of votes necessary for its adoption. The cross-border merger is changing the applicable law and structural aspects of the company, therefore, national laws across the EU require higher thresholds than simple majority. Requiring the Super Majority at this point of negotiating a merger will be a good option, as it will take care of minority shareholder rights in a merger transaction at the voting stage. ${ }^{33}$ 'Regardless of the figure required to adopt a decision by majority, it is determined by both its nominator (the required

\footnotetext{
23 Article 7.

24 Article 8.

25 Mergers Directive Article 10(2).

26 Article 8(4).

27 Mäntysaari (2010) 164.

28 Mäntysaari (2010) 164.

29 Mäntysaari (2010) 164.

30 Mergers Directive Article 9(1).

31 Van der Elst (2012) 46.

32 Van der Elst (2012) 58.

33 Ventoruzzo, (2007) 11.
} 
number) and denominator'. ${ }^{34}$ The denominator can be defined in terms of 'capital', 'votes present and cast', 'voting power' or 'votes of all outstanding shares of the class'. Since not all shareholders may be able to attend the general meeting, votes will be three groups of abstains, 'yea's' or 'nay's'. Additionally, different groups of shares with or without voting power exist in the company which will affect the effectiveness of the denominator. ${ }^{35}$

It is also necessary to remember that 'dissenting minority shareholder' comes into existence after conducting the voting process in general meeting. As a result of voting process, a group of shareholders may find themselves against the will of majority who voted in favor of a merger process and then seek for remedy to resort the balance.

\subsection{The reason behind necessity for protection of minority shareholders in cross-border merger transaction}

Passing through a complicated process like a merger will change different business and structural aspects of a company. Naturally, the level of complication and stress is much higher cross-border mergers, because the company should endure changes regulated under laws of different jurisdictions. Despite the fact that neither the Cross-Border Mergers Directive nor the SE Regulation give a rationale for protection of minority shareholder rights, emergence of such protective measures in the cross-border laws of merger in the EU company law indicates importance of changing the applicable law. ${ }^{36}$ "According to the Directive, effects of a merger are such that one or more companies are dissolved without going into liquidation while their assets and liabilities are transferred to the acquiring company or a newly formed company in exchange for securities, shares or cash payment, offered to their members. ${ }^{37}$ The process will cease the existence of the transferring company. As a result, its shareholders become shareholders in the resulting or acquiring company. Complications will raise when merger has cross-border nature, as applicable law to the transferring company will become the law for the resulting company. Accordingly, the law applicable to shareholder's rights will be the new law. It is not difficult to assume adverse effects of new applicable law on dissenting minority shareholders. ${ }^{38}$

Although, changing the applicable law can be a rationale for positive answer to the question of need for further harmonization of minority shareholder rights, but by no means it can be a sufficient one. The authors believe such line of reasoning does not match modern investment practice. Firstly, minority protection relevant to change of laws only appears to affect rights of the shareholders of the of the transferring company. For example, when a German company acquires a French company, the change of applicable law following the merger process will only affect dissenting shareholders of the French company. However, the resulting company will still be subjected to the law of Germany and descending shareholders of the German company who disagree with affecting the merger will not receive any special protection. This can be explained in two ways: the first one is to transfer the French company to an unknown corporate form subject to German law. Wyckaert and Geens reject this explanation by referring to existing minimal harmonization level of corporate forms in the EU. ${ }^{39}$ Another explanation is necessity for French shareholders to

\footnotetext{
34 Alavi and Khamichonak (2017) 220.

35 Cahn and Donald (2010) 490.

36 Wyckaert and Geens (2008) 49.

37 Alavi and Khamichonak (2017) 215.

38 Ventoruzzo (2007) 11.

39 Wyckaert and Geens (2008) 50.
} 
make themselves familiar with German law in order to understand their rights. In presence of diversified company laws across the EU, this can create a great deal of problems. However, due to the existence of common market, it is well-known that shareholders from different jurisdictions acquire shares in companies subject to laws other than their own. ${ }^{40}$ This argument is recognized in the Shareholders' Rights Directive, harmonizing certain rights of shareholders who own shares in foreign listed companies. ${ }^{41}$

Other occasions which may call for further protection of minority shareholders include: the strong effect of merger on rights of the minority shareholders in a way that they need to have the right for selling-out their shares. ${ }^{42}$ This is an important problem because minority shareholders in the majority of occasions can not to get out of the company without experiencing financial loss. Investing in a company will 'lock in' the capital. A shareholder will have a chance to recover the value of invested capital only with access to exit right. ${ }^{43}$ Additionally, there should be possibility for challenging resolution of general meeting which approves the merger process, terms and conditions of the merger as well as articles of association of the resulting company. ${ }^{44}$ 'The effective confiscation' will be a result of abusive conduct by majority shareholders in absence of exit rights for minority shareholders. ${ }^{45}$

Despite validity of arguments regarding the need for harmonization of minority shareholders, they don't imply any difference between domestic and cross-border mergers. As a result, inclusion of such measures in cross-border merger instruments similar measures are absent in the Third Directive of national mergers is question for the European legislation.

\section{CURRENT STATUS OF MINORITY PROTECTION IN THE EU}

In absence of a union-wide law meeting the requirements of minority shareholders, duty of protecting their rights has been conferred to national laws of the Member States. As a result, in the occasion of a cross-border merger, national laws are the place in which minority shareholders should look for tools to protect their rights.

This issue is directly referred to by the Tenth Directive where the company participating in a cross-border merger transaction is subject to provisions in national law of the Member State which applies to it. ${ }^{46}$ Article 4(1) refers to national law as process of making decision on merger operation as well as protection of shareholders in cross-border context of merger transaction. The article particular provides that Member States may choose to apt for an appropriate national provision in safeguarding the rights of minority shareholders who do not act in accordance with others towards cross-border merger. The word 'may' in this context indicates the non-obligatory nature of providing such protections. The discretionary nature of protections results in significant difference among measures offered by the Member States.

Article 6 provides that at least one month before reaching the agreement in a general meeting with the cross-border merger, draft of common terms should be published in a

40 Wyckaert and Geens (2008) 50.

41 Directive 2007/36/EC of the European Parliament and of the Council of 11 July 2007.

42 Wyckaert and Geens (2008) 51.

43 Moll (2006) 896.

44 Wyckaert and Geens (2008) 51.

45 Moll (2006) 896.

46 Cross-Border Mergers Directive Article 4(1). 
national gazette of the Member State of participating companies. The announcement should indicate respective decisions of each merging company for protecting the rights of their minority shareholders. Also, it is necessary to provide address of venue in which details of above mentioned decisions can be provided for no costs. ${ }^{47}$ Since all shareholders should be aware of meeting agenda and voting conditions in advance, this provision is in accordance with shareholders right for access to information. Additionally, it is provided in Article 10(2) that in presence of compensation measures for minority shareholders of a merging company in a Member State law without preventing cross-border process, such protections can be only recourse after obtaining written agreement of other merging companies. Other merging companies should agree by voting in a general meeting that minority shareholders of that company have the right to due compensation by reference to the competent court of law. Since the resulting company will be subject to the court order and in charge of paying all legal costs, it is necessary to reach approval to protect shareholder rights in advance. ${ }^{48}$

Despite the framework nature of The Tenth Directive minority protection provisions it reemphasizes the need for compliance of national protective measures with free movements of capital and freedom of establishment. It also imposes requirements on the Member States which should be considered by national legislators.

\subsection{Member States without special protection mechanisms}

Reactions of the EU Member States to provisions of the Cross-Border Mergers Directive is by no means harmonious. While some of them have introduced provisions relevant to protection of minority shareholder rights, others like Belgium, Bulgaria, The UK, France and Lithuania do not have any kind of available remedies. ${ }^{49}$

French law only provides protection for dissenting shareholders in domestic mergers, e.g. information rights and the 'abus de majorité'. ${ }^{50}$ Although, the court outcome is nonpredictable. $^{51}$

The Belgian dissenting minority shareholders are totally subjected and bound to the decision of the general meeting. They have no choice other than accepting the process of merger and receiving respective shares in the resulting company. ${ }^{52} \mathrm{In}$ case of facing with any violation of their rights during the process of cross-border merger, dissenting minority shareholders can only claim for liability and misconduct of business managers within the course of merger. ${ }^{53}$ However, cooperatives are exceptions. Their shareholders have the right to exit when the resulting cooperative is not subject to the law of Belgium. ${ }^{54}$

Additionally, Belgian law provides minority shareholders in cross-border mergers right to sue regarding violations that occurred during the cross-border merger process. ${ }^{55}$

No particular mechanism is available under the law of Hungary. Only a compensation is available in case of disagreement with holding shares in resulting company.

47 Cross-Border Mergers Directive, Article 6(2)(c).

48 Wyckaert and Geens (2008) 43.

49 Van Gerven (2011) 23-81.

50 Biermeyer (2013) 430.

51 Biermeyer (2013) 430.

52 Van Gerven (2010) 113.

53 Biermeyer (2013) 269.

54 Biermeyer (2013) 269.

55 Van Gerven (2010) 295-96. 
The English Law does not provide any specific protection to dissenting minority shareholders either. However, it is possible to act against the resolution of the general assembly or require supermajority. Also protection against oppressive resolutions is available. ${ }^{56}$

\subsection{Member States with special protection mechanisms}

Most applied protection mechanisms in the Member States using them are monetary or exit rights. Those Member States that chose to provide special protection mechanisms often resort to variations of a monetary compensation and/or withdrawal right.

In Estonia, adopted provisions in Commercial Code offer a partner or shareholder in a merging company the right to demand payment from acquiring a firm when share exchange ratio is not sufficiently satisfactory. ${ }^{57}$ Further, $\$ 433$ (1) (2) provides that where such protection is not recognized in the law of the other Member State, it can be offered by agreement of all merging companies in the merger agreement ${ }^{58}$ Invalidation of the merger agreement is another remedy provided by $\$ 433.6(3)$ when the share price is set much lower than the fair value. Monetary compensation is the second mechanism considered in $\$ 433.7$ Estonian Commercial Code. When the partner or shareholder of the transferring company rejects the merger agreement, $\$ 433.7$ provides them with an option for requiring the acquiring company to procure their shares in return for monetary value or they are entitled to simply transfer their shares to a third party. However, invalidation of merger agreement on the basis of low setting of share exchange ratio is not permitted under Estonian law. ${ }^{59} \mathrm{In}$ return, a shareholder can require monetary refund from the acquiring company. Failing to meet this demand will entitle dissenting shareholders to claim a fine in addition to the requested refund..$^{60}$ When a merger takes place between different types of companies, Estonian Commercial Code entitles the dissenting shareholders to ask for monetary compensation of exchanged shares from the acquiring company. ${ }^{61}$

Remedies provided for dissenting shareholders in German law can be categorized under three groups: First, an additional monetary compensation when setting the share exchange ratio much lower than the fair value. Second, procurement of dissenting shareholders' shares by the transferring company. Third, challenging the resolution of the general meeting which approved the merger to take place. ${ }^{62}$

Payment of monetary compensation will be through award proceeding specially designed for occasions in which price offer per share is too low or it is more advantageous to be shareholder of the transferring company rather than the acquiring one. In line with Estonian Commercial Code, such remedy will be applicable only when all companies involved in the merger process confirm access to it in the merger agreement or in case that the law applicable to the acquiring company offers similar treatments. Under German law there is a strong possibility to challenge the merger agreement even in cases of not observing information rights of shareholders or not convening the general meeting. As a result, the

56 Van Gerven (2011) 943.

57 Estonian Commercial Code $\S 433(6)$.

58 Estonian Commercial Code $\S 433$ (1)-(2).

59 Estonian Commercial Code $\S 398(2)$.

60 Estonian Commercial Code $\S 398(3)$ and (4).

61 Estonian Commercial Code $\S 404(1)$.

62 Biermeyer (2013) 454. 
merger process will proceed after settling all relevant claims. ${ }^{63}$ German law also provides similar rights for dissenting shareholders in case of domestic mergers.

Protection of minority shareholder rights are also provided in national law of the Czech Republic. The Czech Transformation Act offers three classes of remedies for dissenting shareholders in cross-border mergers. Firstly, when a public company merger with a private foreign company, in similar way to rules subjecting domestic mergers, shareholders have access to the exit right. ${ }^{64}$ While merging with a public foreign company, the merger agreement should reflect the agreement of all parties with the right of Czech shareholders to sell their shares to the resulting company. Secondly, shareholders can file a case against the resulting company where share exchange ratio is not satisfactory. The resulting company will be bound to satisfy dissenting shareholders with monetary compensation. Application of the same rights in all involved Member States and/or agreement of all merging companies with access to such remedies for the Czech shareholders are main prerequisites for invoking it. Thirdly, by claiming violation of fiduciary obligations during merger process, shareholders can bring actions for damages against company's management. ${ }^{65}$

In Denmark, Shareholders of the transferring company have the right to share redemption both in domestic and cross-border mergers. The shelf life of the right is relatively short, as notice should be given before passing of four weeks from general meeting approving the merger. ${ }^{66}$

The same redemption right is provided to dissenting shareholders by Maltese law. The company and shareholders should agree upon terms of redemption. However, in case of their failure, the court's decision on the subject would be binding for all parties. ${ }^{67}$ The legal action should be filed three months before passing approval of the merger in a general meeting. When companies participating in a merger agreement are subject to the law of a Member States that does not provide similar protection mechanisms, it is the merger agreement which should explicitly define an agreement of all parties by Maltese right of shareholder to redeem their shares. ${ }^{68}$

Finnish dissenting shareholders are also provided with the right to redeem their shares in national and cross-border mergers. The redemption price equals to the market price of shares at the time of approval of the merger process will be covered by the resulting company. ${ }^{69}$ Arbitration will be the dispute resolution method in case parties do not agree on the terms of redemption. ${ }^{70}$

Minority protection provisions of the Cross-border Merger Directive is transposed into the national law of Greece. Therefore, Greek dissenting shareholders of cross-border mergers are provided with two treatment mechanisms: Greek dissenting shareholders can file a claim in national court against a Greek company to procure their shares when the resulting company is subject to the law of another Member State. ${ }^{71}$ The other mechanism is applied when the share exchange ratio is not matching the fair market value. In such

${ }^{63}$ Biermeyer (2013) 454.

64 Van Gerven (2010) 161.

65 Van Gerven (2010) 162.

${ }^{66}$ Biermeyer (2013) 370.

67 Van Gerven (2011) 109-10.

68 Biermeyer (2013) 690.

${ }^{69}$ Biermeyer (2013) 407.

70 Biermeyer (2013) 407.

71 Biermeyer (2013) 478. 
situations, shareholders can claim compensation without being able to suspend the event of merger. $^{72}$

Italian law provides withdrawal rights for both to dissenting shareholders as well as abstaining ones. However, this mechanism will be applicable only when the resulting company is subject to the law of an other Member State. Since withdrawal rights in crossborder and domestic mergers are treated the same way under Italian law, the type of a limited liability company and the corresponding rules are elements that define a period for submission of withdrawal request. ${ }^{73}$

Protection of dissenting shareholders is also provided under Latvian law. In contrast with Italian law, only shareholders who attend the general meeting and vote against the merger process are entitled to require share redemption. ${ }^{74}$ They need to raise the claim within two months of the approval of the merger. The amount of redemption is equal to the compensation rate the shareholder would receive in case of liquidation of the company at the time of merger. The resulting company is responsible for redeeming dissenting shareholders. Despite presence of any contrary provisions in the company's articles of association or the body of law, not choosing to ask for redemption may result in alienation of dissenting shareholders from their shares. ${ }^{75}$

Provisions of the Cross-Border Mergers Directive on minority protection are also transposed into the Dutch Commercial Code. In cases other than forming a SE or SCE, dissenting shareholders are eligible for receiving compensation when the resulting company is subject to law of an other Member State. The amount of compensation will be determined by independent experts. Time frame for filing the request for compensation is one month from the date of the general meeting approving the merger process. The merger process would not proceed before settling the compensation rate and all relevant requests from dissenting shareholders. ${ }^{76}$

The law of Spain provides the right to exit for dissenting shareholder. Unlike crossborder mergers, exit right is not available for domestic ones, with the exception of cases where the company is transformed or availability of similar provisions in the bylaws. To be effected, written demand to exit must be delivered within a maximum of one month after receiving merger's notice. ${ }^{77}$

Study of the protection mechanisms applied by the Member States results in few conclusions. Firstly, there are few remedies available for dissenting shareholders. Interestingly, national laws of Member State offer similar measures: the exit right, redemption or repurchase of shares; further compensation when share exchange ratio is not sufficient and legal action against misconduct of company authorities.

Secondly, all remedies offered by Member States are applicable only when they are offered by governing law which the resulting company is subject to or protections are agreed upon by all merging companies in the draft of merger's terms. The conclusion would be that despite absence of a substantive system for regulating cross-border mergers at the EU level, a basic 'fall back' system exists. Since only few of the Member States have not effected respective provisions in their national regulations, it is still possible to have an

72 Biermeyer (2013) 478.

73 Biermeyer (2013) 555.

74 Biermeyer (2013) 595.

75 Biermeyer (2013) 596.

76 Biermeyer (2013) 718-19.

77 Biermeyer (2013) 900. 
unobtrusive transaction. This happens when the merger takes place between firms from Member States having no particular provisions with firms in Member States with provisions for protecting descending shareholders. Therefore, it is possible to treat dissenting shareholders properly on the basis of mutual agreement of all firms involved in the merger process.

A valid question would be why the acquiring company, which is not subjected to mandatory regulatory compensation, will agree to a binding obligation? The answer to this question takes us back the principle reasons for a merger process to take place. The acquiring company wishes to expand. Such expansion could have different forms, including geographical expansion, market diversification or even entering into new businesses. ${ }^{78}$ Synergy is an other outstanding reason behind cross-border mergers to take place. Creation of more shareholder value by joining forces with two or more companies rather than acting individually is a well-known and appreciated business notion. ${ }^{79}$ Strategic realignment is the next driving force which suggests that companies engage in merger activity to react faster to changes in the external environment (regulatory environment and technological innovation $)^{80}$. Access to new markets while enjoying an established marketing channel there is yet another reason for getting involved in a cross-border merger process. ${ }^{81}$ In tune with reaping the benefits of technological advancement and securing the know-how, crossborder mergers are also motivated by accessing proprietary assets (patents, brand names, licenses and alike), which are not available on domestic markets. Any of the above mentioned reasons or a combination of them can be a valid reason for a company to offer special protections to dissenting shareholders in return for preserving the transaction.

The relatively recent consultation of the Commission in 2014 on the effectiveness of the EU rules relating to cross-border mergers and divisions targeted respective stockholders. ${ }^{82}$ The outcome with 151 contributions was published in the second half of $2015 .^{83}$ The Respondents consisted of a wide range of stockholders including scholars, practitioners, public authorities, chambers of commerce, business organizations and others. Among others, they answered to three most noteworthy questions relating to minority shareholder protection and need for harmonization of the rights of minority shareholders in cross-border mergers; if the date in which minority shareholders are eligible to exercise of those rights needs to be harmonized and finally, if the time period in which minority shareholders can exercise respective rights needs to be harmonized. ${ }^{84}$ Over 60 percent of respondents gave positive answer to all three questions. (over $60 \%$ ). However, it is also necessary to mention that high number of respondents did not agree with harmonization in the areas $(35 \%, 25 \%$ and $31 \%$, respectively). Disagreement within a considerable percentage of stakeholders regarding the need for further harmonization of dissenting shareholders' rights in respective areas illustrates that the issue of minority protection in cross-border mergers is the centerpiece of an ongoing debate.

78 Moeller and Brady, (2007) 117.

79 DePamphilis, (2011) 4-5.

80 DePamphilis, (2011) 7-9.

81 Rusu, (2006) 15.

82 European Commission Press Release, Daily News 08.09.2014.

83 European Commission <http://ec.europa.eu/justice/civil/company-law/eu-company-law/ index_en.htm.> Accessed 20 December 2016.

${ }^{84}$ European Commission $<\mathrm{http}$ //ec.europa.eu/internal_market/consultations/2014/cross-bordermergers-divisions/docs/summary-of-responses_en.pdf>. Accessed on 20December 2016. 
To start with no harmonization is needed due to the sufficiency of protection provided by national laws. ${ }^{85}$

Furthermore, particular rights, like the right to block a merger, can be used abusively. In fact, protection mechanisms offered to minority shareholders should be in balance with interests of the company, while considering the deterioration of their position as a result of the merger. As a result, some treatments offered to shareholders (e.g. the right to compensation or the right to challenge the share exchange ratio) are considered more favorable than others in order to keep the balance and to not let them influence the overall corporate decision regarding merger process. ${ }^{86}$

Finally, a specially designed protection for minority shareholders in cross-border mergers is not necessary as domestic and cross-border mergers have no difference in this respect. ${ }^{87}$ The response to the Commission's consultation from the Council of Bars and Law Societies of Europe (CCBE) answered 'No' to all three questions regarding harmonization. Indeed, as elaborated earlier in the paper, there is no justified need for introducing specific minority protection mechanisms on the European level. It does not mean, however, that minority protection shall be abandoned within the framework of European company law is concerned and to be left solely to the Member States' initiative.

In light of the existing domestic rules and the umbrella provision in Article 4(2) of the Cross-Border Mergers Directive, authors submit that no further harmonization of substantive rules regarding minority shareholder protection shall be introduced by the European legislation. Considering current circumstances of existing variety in national laws, the importance of a shareholder's right to be heard, and the importance of further integration of the common market as well as the role that freedom of establishment plays in pursuing this goal, the authors support the idea of bringing minority protection rights to the spotlight in ways other than full or partial harmonization.

\section{CONCLUSION}

The legislative framework covering cross-border mergers in the EU is the most soundly functioning to date. The breaking down of national barriers and making transnational mergers possible has come a long way both at the hands of the European legislation and the ECJ. The business community regards the merger process as one of the most complicated of its processes, that is almost unavoidable during the process of trade expansion for many international firms. As a result, it is necessary to expect the settlement of numerous problems before access a comprehensive European legislation in this area. Some the important problems could be short listed, such as tax law differences among the Member States, employment issues, settlement of creditors rights and last but not the least, protecting the rights of minority shareholders. Among others, this paper focused on protection of rights of minority shareholders in the existing framework of the European Union for cross-border merger transactions.

An uncontestable expectation of shareholders, as owners of company shares, is to have their legitimate interests protected within the course of business. If not, they can use decision making rights attached to their shares, in order to change the composition of the

85 European Commission, (October 2015) 9.

${ }^{86}$ European Commission, (October 2015) 10.

87 Council of Bars and Law Societies of Europe <http://www.ccbe.eu/fileadmin/user_upload/ NTCdocument/22022015_EN_CCBE_Con1_1424700904.pdf $>$ Accessed 20 December 2016. 
company's management team. A merger, particularly cross-border merger, affects the structure and the even applicable laws of the company significantly. Undergoing changes of this kind increases the exposure to multiple types of risk for different stakeholders. Stakeholders with less bargaining power, e.g. minority dissenting shareholders, will see themselves in a more aggravated situation. They may feel that their position has worsened without their consent as result of disparities in national company laws across the EU and conditions of a resulting company.

Despite recognition of the need for protection of dissenting minority shareholders' rights in European Law, there is no harmonized approach to the issue. The current approach of the European law in the Cross-Border Mergers Directive is limited to a framework approach, which should be implemented in national laws of the Member States. Nonsurprisingly, the Member States took a diversified approach to the protection of dissenting minority shareholders' rights, varying from elaboration of special mechanisms for this purpose, to absence of any protective mechanism. The existing disparity of approach in the Member States laws is inconsistent with the belief that minority shareholders should be protected more within the framework of European company laws. In contrast with the existing general belief, this paper approached the current level of harmonization from a company's perspective, rather that of the shareholders'. Therefore, the crucial question was determining the beneficial, determining or neutral effect of the further harmonizing of dissenting minority shareholder rights in the cross-border merger process. Accordingly, the study's focus shifted towards risks of postponement of progress of cross-border merger processes until settlement of minority shareholder claims in the current situation of underharmonization and varying national provisions.

After analyzing provisions of the Cross-Border Mergers Directive together with implemented decisions of the Member States, this paper disagrees with the need for further harmonization of protection from minority shareholders at the European level. The framework approach to minority shareholders' protection has no negative effect on the process of cross-border mergers, as a safety mechanism is already provided in national laws of the Member States. On one hand, the company does not consider dissenting minority shareholders a hurdle in progressing the process of a cross-border merger transaction. On the other hand, shareholders have access to remedial rights in the framework approach of the European Cross-Border Mergers Directive, as well as protection mechanisms in the law of the Member States which they are subject to. In fact, full harmonization would be considered as rather unwelcome.

Based on the findings, the paper proposes to shift the focus from harmonizing substantive rules of minority protection to facilitating the information exchange among the Member States with regard to the existing national provisions. Additionally, the introduction of a EU-level provision mandating merging companies to provide for a negotiated ad hoc protection mechanism could provide for an extra incentive for the companies to account for their minority shareholders' interests.

\section{LITERATURE}

Alavi. Hamed and Khamichonak, Tatsiana, 'European Provisions for the Protection of Dissenting Shareholders within the Framework of Cross-border Mergers' (2016). Vol. 16, No. 3. Romanian Journal of European Affairs 72-86.

Alavi, Hamed and Khamichonak, Tatsiana, 'Protection of Dissenting Shareholders in the EU CrossBorder Mergers Framework: A call for Further Harmonization?' (2017) 21(3) TRAMES: A Journal of the Humanities \& Social Sciences 215-32. 
Biermeyer, Thomas Study on the application of the cross-border mergers directive. (The European Union. Bech-Bruun, and Lexicdale 2013). <http://ec.europa.eu/internal_market/company/docs/ mergers/131007_study-cross-border-merger-directive_en.pdf $>$ accessed 20 December 2016.

Cahn, Andreas and Donald, David C., Comparative Company Law (Cambridge University Press 2010).

De Pamphilis, Donald, Mergers and Acquisitions Basics (Elsevier 2011).

Donald, David C., 'Shareholder Voice and Its Opponents' (2005)40/06 Institute for Law and Finance, Johann Wolfgang Goethe-Universitaet, Working Paper Series 1-60.

European Commission Press Release, Daily News 08.09.2014.

Laprade, Frank Martin, Study on the Rights and Obligations of Shareholders (European Parliament's Committee on Legal Affairs 2012).

Mäntysaari, Petri, The Law of Corporate Finance: General Principles and EU Law (Springer 2010).

Moeller, Scot and Brady, Chris Intelligent M\&A ( John Wiley \& Sons Ltd 2007).

Moll, Douglas, 'Minority Oppression \& the Limited Liability Company: Learning (or Not) from Close Corporation History' (2005) 40 Wake Forest Law Review - Public Law and Legal Theory Series 2006-A-01. 883-975

Perakis, Evanghelos, Rights of Minority Shareholders, General report for the XVI Congress of the International Academy of Comparative Law (Bruylant, 2004).

Rusu, Catalin Stefan, 'A few basic considerations on the importance of cross-border mergers and acquisitions issue within the European context' (2006) 1 Studia Universitatis Babes-Bolyai Jurisprudentia 15-45.

Smith, Adam, An inquiry into the Nature and Causes of the Wealth of Nations (W. Strahan and T. Cagell 1776).

Van der Elst, Christoph, 'Shareholder Rights and Shareholder Activism: The Role of the General Meeting of Shareholders' (2012) LX (3) Belgrade Law Review 39-64.

Van Gerven, Drik, Cross-Border mergers in Europe Volume 1 (Cambridge University Press 2010).

Van Gerven, Drik. Cross-Border mergers in Europe Volume 2 (Cambridge University Press 2011).

Wearing, Robert, Cases in Corporate Governance (SAGE Publications 2005).

Wyckaert, Marieke and Geens, Koen, 'Cross-border mergers and minority protection. An open-ended harmonisation' (2008) 4 (1) Utrecht Law Review 40-52.

Ventoruzzo, Marco 'Cross-border Mergers, Change of Applicable Corporate Laws and Protection of Dissenting Shareholders: Withdrawal Rights under Italian Law' (2007) 16 Bocconi Legal Studies Research Paper 1-24. 